\title{
Financial Crises and the Future of the Real Economy
}

\author{
Paweł Fiedor
}

\begin{abstract}
Current research on the connection between financial markets and real economy is inconclusive. We look at this relationship by analyzing statistical interconnections between stock prices, the potential for growth in companies and macroeconomic aggregates. Such analysis shows weak bond between real economy and financial markets in Poland between 1997 and 2012, thus corroborating other recent research. Further we investigate the causes of such weak relationship and find that research showed a strong relationship a few decades ago, but not in the last 30 years, indicating a structural change in the last 50 years. We believe that the cause may be connected with the abolition of the Bretton Woods Agreement, the propagation of fiat money, and the following rise of the debt-driven capital markets, as well as the steady decline in labor share connected with sharp increases in labor productivity in the First World. We investigate the possible results of this and find not only a possibility of an abundance of crises in the future but also a possible limit to economic growth. We also review the possible answers to the problem, and find that the answer lies in disincentivizing the speculative nature of modern financial markets and reforming current monetary system, i.e. fiat money.
\end{abstract}

Index Terms-Financial markets, real economy, labor share, economic growth.

\section{FinANCIAL MARKETS AND REAL ECONOMY}

The financial crisis of 2008 sparked numerous investigations into the nature of the connection between financial markets and real economy, both on microeconomic and macroeconomic levels. The macroeconomic research necessarily misses a lot of the details, and the microeconomic research cannot be fully representative as the data is available only for the publicly listed companies. Most of recent studies looked into the transmission of the effects of a financial crisis into the real economy and not the interrelationship as such. One study looked at 7722 non-financial firms in 42 countries, showing that the crisis had a bigger negative impact on firms with greater sensitivity to business cycle and trade developments, particularly in countries more open to trade. Financial openness made limited difference however [1]. Another study showed that the financial crisis can be characterized by strong contagion effects among aggregate stock markets and among financial sector stocks. However the evidence for contagion of the sectors representing the real economy such as consumer goods, industrials, telecommunications and technology is mixed. In no specific region or distinct group of countries have markets been immune to the shocks associated with the crisis. Strong evidence for contagion in the financial sector found in the study demonstrates the importance of this sector in the crisis.

Manuscript received March 25, 2013; revised May 30, 2013.

Pawe Fiedor is with the Cracow University of Economics, Poland (e-mail: s801dok@wizard.uek.krakow.pl).
The significantly weaker evidence for contagion of the real economy sectors such as healthcare, telecommunications and technology implies that investors distinguished between sectors of different characteristics and therefore maintained the effectiveness of diversification [2]. A study of Colombian economy found that the rate of interest is the connector between the two markets (financial and real), which is modified by changing the composition of the portfolios and also that the Colombian economy has imbalances in the market for financial assets that alter the real economy [3].

To investigate the relationship between financial markets and the real economy we have found 53 companies listed on the main Polish stock market (GPW) continuously between 1997 and 2012. This sample may not be representative for all Polish companies, but since the publicly listed companies are the only strong link between the real economy and financial markets, such an analysis may bring interesting and valid results. The study has been validated by a study of a larger sample of companies over a shorter period (see results review below). While the results will directly concern only Polish economy, the homogeneousness and globalization of the financial markets in Europe and the world [4] suggest that the results will be also indirectly hinting the global situation. The financial market is in this case represented by the prices of the shares of those companies over the 16 data points (end of each respective year). The prices are regulated purely by financial markets and represent the core of the financial markets. The real economy is divided into two segments in this study. First we look at micro level represented by a model for bankruptcy prediction, which is supposed to show an aggregate estimation of the situation of the company, particularly its capacity for growth. The class of models for predicting bankruptcy using discriminant analysis has been established by Edward Altman [5]. Altman's z-score would not be relevant for Polish companies 30 years after it has been created. In fact discriminant analysis makes it hard to justify the model's usefulness outside the specific date and region where it has been created, which does not diminish the practical use of those models. We have chosen one of the seven models developed by Polish Academy of Sciences [6]. The model is called PAN-F and has been verified as one of the best suited models for Polish companies [7]. Therefore we believe that it may correctly represent the aggregate situation of a company, and its potential for growth or bankruptcy. The model is presented below:

$$
\begin{aligned}
& P A N-F=-2.478+9.478 \frac{W O}{A}+3.613 \frac{K W}{A}+ \\
& +3.246 \frac{(W N+A M)}{Z}+0.455 \frac{M O}{Z K T}+0.802 \frac{P}{A}
\end{aligned}
$$

where

- WO-profit (loss) from operating activity;

- A-total assets; 
- KW-shareholders' equity;

- WN-net profit (loss);

- AM-depreciation;

- Z-liabilities;

- MO-current assets;

- ZKT-short-term liabilities;

- P-revenues from sales of products, goods and materials.

The macro level is represented by GDP and aggregate investments. These values are provided by Central Statistical Office of Poland. We calculate correlation coefficients for every company between share prices and PAN-F model score, share prices and GDP, and lastly share prices and investment levels. All those are calculated in the standard fashion (solid lines) as well as with one year lag both ways to show if perhaps there is a one-directional relationship between the two (dotted lines for lagged prices and dashed lines for the opposite). The results of those in form of cumulative distribution functions are shown below. As can be seen the correlation coefficients have a slight tendency to be positive, but in most cases they're not statistically significant (for PAN-F only 10 out of 53 statistically significantly differ from 0 and the means of correlation coefficients are as follows: $0.169,0.139 \& 0.086$, for GDP 26 are statistically significant but 13 of them on the negative side and the other 13 on the positive side and the means take the values of $-0.059,0.005 \&$ -0.037 , for investments it's 20 , and as with GDP they are equally distributed on both ends with means of $-0.019,0.150$ $\&$-0.161). Apart from the presented study other variables have been tested, i.a. dynamics of the above. Also a sample of around 200 companies over a shorter period has been studied. In neither of those have the results been significantly different, therefore those have not been presented in detail. Thus in general we conclude that there is no strong positive or negative connection between the financial markets and the real economy in Poland, both on microeconomic and macroeconomic levels. This is somewhat corroborated by findings from Argentina, Brazil, Chile and Mexico for the period 1993-2005, where researchers have found a weak connection between financial markets and real economy. Interestingly this connection was only one-directional, from the stock market to the real economy, implying that even if real economy is dependent on financial markets, the financial markets are not dependent on the real economy [8]. (Fig. 1-3) and Table I.

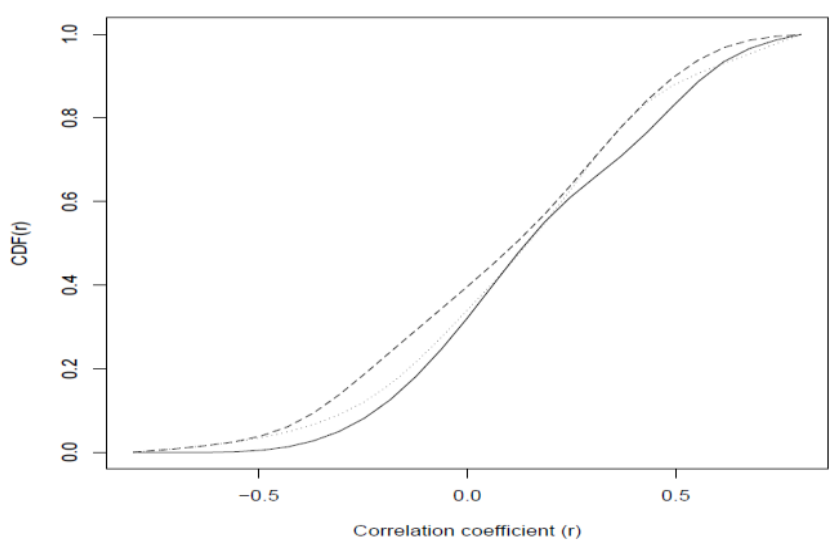

Fig. 1. Correlation between stock prices and PAN-F model score (CDF).

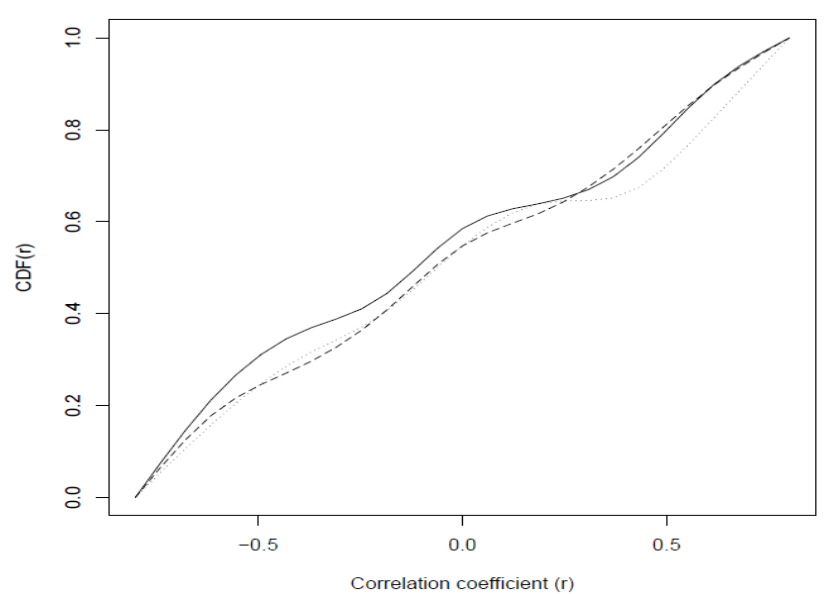

Fig. 2. Correlation between stock prices and GDP (CDF).

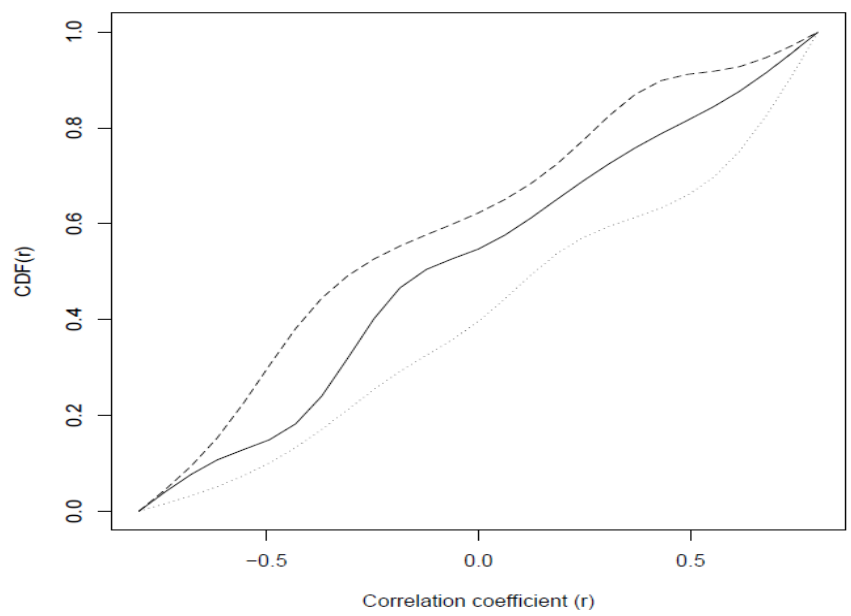

Fig. 3. Correlation between stock prices and investments (CDF).

TABLE I: THE ANALYZED COMPANIES

\begin{tabular}{llll}
\hline \hline ADVADIS & ELBUDOWA & LENTEX & RAFAKO \\
ALMA & ENAP & PPWK & RELPOL \\
AMICA & ENERGOPLD & MIESZKO & REMAK \\
AMPLI & FERRUM & MOSTALWAR & ROPCZYCE \\
APATOR & FORTE & MOSTALEXP & SANOK \\
ATLANTIS & HUTMEN & MOSTALZAB & STALPROD \\
BUDIMEX & IGROUP & NOVITA & STALEXP \\
BORYSZEW & INDYKPOL & ORBIS & ULMA \\
BEST & IMPEXMET & PAGED & VISTULA \\
BYTOM & KGHM & POINTGROUP & MASTERS \\
JUTRZENKA & KOMPAP & PEPEES & ZYWIEC \\
DEBICA & KRUSZWICA & PROCHNIK & \\
ECHO & KETY & PROCHEM & \\
EFEKT & LUBAWA & POLIMEXMS & \\
\hline \hline
\end{tabular}

\section{CAuses - The Perpetual Money Machine}

It is particularly interesting to know why financial markets and the real economy are not closely tied together. While earlier economists believed that the relationship between financial markets and the real economy has been strongly positive [9], lately some economists started doubting this [10, 11]. Classically it was said that financial markets contribute to the real economy by greater efficiency in the allocation of capital as a proportion of financial savings in total wealth increases; more attractive instruments and vehicles for savings; financial instruments combining and diversifying risk; decreased costs of acquisition and processing of information (and associated improvements in the allocation of resources); and increased specialization and the adoption of new technologies [12]. Most of the arguments for the disconnection between financial markets and real economy 
stem from the insistence on the imperfect information being held by the investors on financial markets, therefore this shift is parallel to the shift away from the assumption of efficient markets [13]. It's possible that a link which previously existed has been broken. Binswanger showed that return on equity is no longer a good indicator of economic activity in the real economy from the eighties (while it was shown to be before using the same methodology [14]), that is from the time when global financial capital flows increased significantly [15]. But one of the reasons is rooted within the economic growth itself. Labor productivity (LP) is defined as GDP divided by the cost of labor in the economy (W) [16]. But labor share (LS) is defined as cost of labor (wages) divided by GDP. Therefore:

$$
\begin{aligned}
& L P=G D P / W \\
& L S=W / G D P \\
& L S=1 / L P
\end{aligned}
$$

Thus the higher the labor productivity (one of the main signs of economic progress) the smaller share of value added to the economy is going to the labor and the higher share is going to the capital providers [17]. This effect is partly caused by growing international trade [18]. This has various consequences to the whole economic system. Social pressure has been reviewed in [19]. Additionally the labor is using their share of money mostly in the real economy when buying necessities, and therefore labor share is mostly used to stimulate demand. Meanwhile the money held by capital is used in a much smaller degree to stimulate demand in the real economy and is instead held not invested or invested in the financial markets, which, as we've shown, are not necessarily connected to the real economy (there is no relationship between lagged financial wealth growth and current spending growth [20]). This is particularly true of investments in the increasingly popular derivatives, as opposed to common stock. This money is then not helping the real economy, particularly in the times of crisis, when demand is crucial to recovery. Thus it seems that the more advanced the economy is the harder will it be for it to fight the crises, especially as the effects of a crisis will most likely surface not as excess supply which could stimulate further demand but as excess demand for debt securities [21].

This also means that there seems to be a limit beyond which companies will not be able to grow, as the labor share will be too small to maintain the return on capital of real economic entities. Beyond this limit the money will be invested not in real companies but merely in perpetual money machine [22], which consists in the debt-driven modern financial markets.

The limits on growth of real economies can also be deduced from the computational limitations, which are driving the economic growth in the last 50 years [23]. The economy cannot grow indefinitely at a steady rate, which has been proposed by M. Dobija in the form of economic constant [24]. We know that the capital has not been growing by the proposed $8 \%$ every year in all of history, as it is mathematically unsupportable (our estimation brings global capital to an absurd 1 cent worth in the year 1500 using those assumptions), and we know it cannot grow so fast in the future [25], even if only because of physical limitations.

It does seem that the capital knows the grim future of the real economy and shifted its attention away from it and towards the perpetual, self-serving money machine, which can operate outside the boundaries provided by the economic reality. It appears to be the price for paid fiat money being a fundamental block of the modern socio-economic systems, which is opposing the natural laws of capital preservation [26].

\section{RESUlTS - THE UNFADING CRISES}

This may bring a sovereign debt crisis. The lack in demand for real products as opposed to debt securities in the times of crisis makes it harder for companies to justify investments, even though companies have an excess of money during the last financial crisis [27]. As it is increasingly hard to stimulate investments the interest rates are being kept very low. This means that bonds are relatively attractive, and performing well in around the financial crisis of 2007. Therefore it is possible that the increased demand on sovereign debt now and in the coming years may stimulate yet another bubble and crisis.

But most importantly this will arguably have strong consequences for the economy as a whole. Even in times of prosperity in the future we should see a growth in the real economy that will not be as fast as we're used to, and slowing steadily in the countries where the labor productivity is becoming very high. This insight is corroborated by a research showing that increase in labor productivity in United Arab Emirates gave rise to reduction in economic growth [28], though other researchers believe in strong positive relationship between growth and labor productivity [29]. We believe that this relationship is positive until labor share is too small to facilitate further growth in real economy. The overall growth will be shifting more and more towards the financial markets, and presumably closer to gambling than betting on future actions of real economy [30]. The rising popularity of high-frequency trading, trading at intervals shorter than any possibly intelligible change in the market data (yet another proof against the market efficiency hypothesis), is an example of this trend [31].

The situation will conceivably be even worse in terms of crises, which can be seen happening today. Crises, and even financial crises not having much to do with the real economy, are hurting the less wealthy more [32], and therefore making it harder for the sloppy demand to pick up (as demand is often wage-led [33]). That was the case in the past too, the difference is that with time the labor share will be declining further and there will be less wealth distributed into the wage-led demand of the real economy in the first place, making it so much harder for the real economy to get out of crisis, while financial markets will probably get out of crisis much faster due to the capital share being much higher and the weak interdependence between real economy and the financial sector.

One has to wonder whether the fact that lower labor share constraints growth and financial crises lower labor share [34] will not lead to a situation where in the end the labor share 
will be so low that the real economy will not be able to get out of a crisis and will maintain its existence in a state of permanent crisis until a time where perhaps new economic paradigm will be created [35]. The financial markets could, as we see in today's world, create wealth for the capital quite independently of this process. Some evidence of the world facing this way can be found in the fact that economic crises are becoming more frequent in the last 40 years [22].

\section{ANSWER - THE TRIAL OF MONEY}

There seem to be virtually no answer to this process being implemented anywhere in the world. The immediate steps which could help slow down the progress of this would have to try to strengthen the bond between the real economy and the financial markets, or, in other words, disincentivizing treating financial markets as a gambling device. There are only few signs of those actions, most notably with certain institutions trying to implement financial transaction taxes aimed at limiting speculation and high-frequency trading [36] But those ideas seem to be going nowhere, with powerful lobbies working against them, even though these solutions would only be changing the situation slightly.

A real solution would have to be much stronger, therefore also one which would not be possible to implement now, as hinted by the above. Perhaps the best solution to this problem known in literature is the idea of M. Dobija to abolish fiat money and link the currency creation with performed labor (as labor creates value). Therefore there would be a much stronger link between the financial markets, whose supply of money would depend on actual labor, and the real economy where the labor is performed [37].

\section{CONCLUSIONS AND FURTHER RESEARCH}

We have established that the link between financial markets and real economy is weakened by the nature of modern economic systems. Research in different countries, using different methodologies, show differing results and therefore further research is necessary. It seems that such weak connection together with a strong connection between labor share and economic stability may lead to a spiral of economic instability. Further research in the economic equilibrium under very low labor share should be performed. As there seem to be no solutions currently being implemented in the economy there is also a need to review possible answers to the impending spiral of crises, most notably the current monetary system and its tenets, and the building blocks of the financial markets, which are increasingly disconnected from the real economic activity.

\section{REFERENCES}

[1] S. Claessens, H. Tong and S.-J. Wei, "From the financial crisis to the real economy: Using firm-level data to identify transmission channels," Journal of International Economics, vol. 88, no. 2, pp. 375-87, 2012.

[2] D. G. Baur, "Financial contagion and the real economy," Journal of Banking and Finance, vol. 36, no. 10, pp. 2680-92, 2012.

[3] G. Leon and J. Mauricio, "Una evidencia en Colombia de la relacion entre el mercado de activos financieros y la economia real.," Apuntes del CENES, vol. 29, no. 49, pp. 95-122, 2010.

[4] Y. Liang, "Global Imbalances and Financial Crisis: Financial Globalization as a Common Cause," Journal of Economic Issues, vol. 46, no. 2, pp. 353-62, 2012.
[5] E. I. Altman, "Financial ratios, discriminant analysis and the prediction of corporate bankruptcy," Journal of Finance, vol. 23, no. 4, 1968.

[6] E. Mączyńska and M. Zawadzki, "Dyskryminacyjne modele predykcji bankructwa przedsiębiorstw," Ekonomista, vol. 2, 2006.

[7] J. Kisielińska and A. Waszkowski, "Polskie modele do prognozowania bankructwa przedsiębiorstw i ich weryfikacja," Zeszyty Naukowe Szkoły Głównej Gospodarstwa Wiejskiego w Warszawie, no. 82, pp. 17-31, 2010.

[8] S. Brugger and E. Ortiz, "Mercados accionarios y su relacion con la economia real en America Latina.," Problemas del Desarrollo, vol. 43, no. 168 , pp. $63-93,2012$

[9] J. G. Gurley and E. S. Shaw, "Financial aspects of economic development," American Economic Review, vol. 45, no. 4, pp. 515-538, 1955.

[10] J. Stiglitz, Selected Works of Joseph E. Stiglitz, Volume I: Information and Economic Analysis, Oxford: Oxford University Press, 2008.

[11] A. Singh and B. Weiss, "Emerging stock markets, portfolio capital flows and long-term economic growth: micro and macro perspectives," World Development, vol. 29, pp. 607-622, 1998.

[12] A. A. Enisan and A. Olufisayo, "Stock market development and economic growth; evidence from seven sub-saharan african countries," Journal of Economics and Business, vol. 61, pp. 162-171, 2009.

[13] E. Fama, "Efficient capital markets: II," The Journal of Finance, vol. 46 , no. 5 , pp. $1575-1617,1991$.

[14] E. Fama, "Stock returns and real activity," Journal of Finance, vol. 45, no. 4, pp. 1089-1108, 1990.

[15] M. Binswanger, "Stock returns and real activity. Is there still a connection?" Applied Financial Economics, vol. 10, no. 4, pp. 90-99, 2004.

[16] M. Dobija, "Labor productivity vs. minimum wage level," Modern Economy, vol. 2, no. 5, pp. 780-787, 2011.

[17] P. Duenhaupt, "Financialization and the rentier income share evidence from the USA and Germany," International Review of Applied Economics, vol. 26, no. 4, pp. 465-87, 2012.

[18] P. Böckerman and M. Malirantay, "Globalization, creative destruction, and labour share change: evidence on the determinants and mechanisms from longitudinal plant-level data," Oxford Economic Papers, no. 64, p. 259-280, 2012.

[19] M. Karanassou and H. Sala, "Inequality and Employment Sensitivities to the Falling Labour Share," The Economic and Social Review, vol. 43, no. 3, pp. 343-376, 2012.

[20] X. Zhou and C. D. Carroll, "Dynamics of wealth and consumption: new and improved measures for U.S. states," The B.E. Journal of Macroeconomics, vol. 12, no. 2, 2012.

[21] P. Lysandrou, "Global inequality, wealth concentration and the subprime crisis: A marxian commodity theory analysis," Development and Change, vol. 42, no. 1, pp. 183-208, 2011.

[22] P. Cauwels and D. Sornette, "The illusion of the perpetual money machine," Swiss Finance Institute Research Papers, no. 12-40, 2012.

[23] L. Krauss and G. D. Starkman. (2004). Universal limits on computation. [Online]. Available: http://arxiv.org/abs/astro-ph/0404510

[24] M. Dobija, "Monetary causes of the financial systems instability," Cracow University of Economics Working Paper, no. 9/KR/2/08/S/426, 2008.

[25] I. Seidl and A. Zahrnt, “Abhängigkeit vom wirtschaftswachstum als hindernis für eine politik innerhalb der limits to growth. perspektiven für eine Postwachstumsgesellschaft," GAIA: Ecological Perspectives for Science \& Society, vol. 21, no. 2, pp. 108-115, 2012

[26] M. Dobija, Ed., Kapitat ludzki w perspektywie ekonomicznej, Kraków: Wydawnictwo Uniwersytetu Ekonomicznego w Krakowie, 2011.

[27] M. B. Lozano, "Analysing the Effect of Excess Cash Accumulation on Financial Decisions," Applied Economics, vol. 44, no. 21, pp. 2687-98, 2012.

[28] J. Alani, "Effects of technological progress and productivity on economic growth in United Arab Emirates," Skyline Business Journal, vol. 8, no. 1, pp. 1-9, 2013.

[29] T. Uskova, "Labor productivity: the main economic growth factor," Problems of Economic Transition, vol. 53, no. 1, pp. 51-62, 2010.

[30] D. Paton, D. Siegel, and L. V. Williams, "The growth of gambling and prediction markets: economic and financial implications," Economica, vol. 76, no. 302, pp. 219-224, 2009.

[31] R. Jarrow and P. Protter, "A dysfunctional role of high frequency trading in electronic markets," International Journal of Theoretical \& Applied Finance, vol. 15, no. 3, pp. 1-15, 2012.

[32] O. Furutan, "The role of the widening gap between the rich and the poor in the recent financial crises," Research in Business \& Economics Journal, vol. 4, pp. 1-7, 2011.

[33] E. Stockhammer and Ö. Onaran, "Rethinking wage policy in the face of the Euro crisis. Implications of the wage-led demand regime," 
International Review of Applied Economics, vol. 26, no. 2, pp. 191-203, 2012.

[34] E. Orgiazzi, "Financial development and instability: the role of the labour share," Research in Economics, vol. 62, no. 4, pp. 215-236, 2008.

[35] S. Mollah, "Financial crisis: is there a need for paradigm shift?" Studies in Economics and Finance, vol. 27, no. 2, 2010.

[36] J. Almenber and M. Wiberg, "Taxing financial transactions," Sveriges Riksbank Economic Review, no. 1, pp. 84-102, 2012.

[37] M. Dobija, "Theoretical grounds of public finance reform," Argumenta Oecomica Cracoviensia, no. 5, 2009.

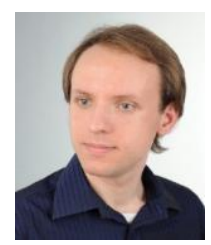

Pawel Fiedor was born in Żywiec, Poland on May 2 , 1986. He obtained Master of Science degree in Information Management from Cracow University of Economics (Kraków, Poland) in 2010. He is currently a $\mathrm{PhD}$ candidate in economics therein.He works in financial industry, the press and education. His research interests include economics of information, econophysics and knowledge management. 